\title{
Reestablishment of the name Skeneoides formosissima (Brugnone, 1873) instead of S. jeffreysii (Monterosato, 1872) nomen nudum (Gastropoda Vetigastropoda Skeneidae)
}

\author{
Italo Nofroni' \& Walter Renda ${ }^{2 *}$ \\ ${ }^{1}$ Via B. Croce 97, 00142 Rome, Italy: e-mail; italo.nofroni@uniroma1.it \\ ${ }^{2}$ Via Bologna 18/A, 87032 Amantea (Cosenza), Italy; e-mail: w.renda1@tin.it \\ *Corresponding author
}

\begin{abstract}
On the basis of bibliographical researches, it is demonstrated that Circulus jeffreysii Monterosato, 1872 (Gastropoda Vetigastropoda Skeneidae W. Clark, 1851) is a nomen nudum, and not a replacement name for Delphinula costata Danilo, 1856. The first validly described name is Circulus formosissimus Brugnone, 1873, therefore, in the light of the current systematic, the current name of the uncommun Sicilian species is Skeneoides formosissima (Brugnone, 1873). Some remarks are included on the differentiation between Skeneoides formosissima and S. exilissima (Philippi, 1844).
\end{abstract}

KEY WORDS Taxonomy; Nomenclature; Mediterranean Sea.

Received 26.07.2021; accepted 16.10.2021; published online 04.11.2021

\section{INTRODUCTION}

During our research on the family Skeneidae W. Clark, 1851 (Gastropoda Vetigastropoda) in the Mediterranean Sea, while consulting the literature on Skeneoides jeffreysii (Monterosato, 1872), we came across some nomenclatural problems which required to be solved.

According to Warén (1992: 157), the name Circulus jeffreysii was proposed (1872: 31) as a nomen novum by Monterosato for Delphinula costata Danilo, 1856 (a junior homonym of Delphinula costata Brown, 1827), a species described for the waters of Zadar (Croatia, upper Adriatic Sea).

This claim surprised us, since it is known that $S$. jeffreysii is a species occurring in the lower Adriatic Sea never reported for the upper Adriatic to our knowledge: the northernmost Adriatic record is by
Romani et al. (2018: 8, fig. 3B) comes from the Island of Lastovo (southeastern Adriatic).

In order to further investigate the problem, we examined the original description of Delphinula costata (i.e., Danilo, 1856) where on the first page (pag. 107) it is reported that "Tutte le misure sono espresse in linee di Vienna [All measurements are expressed in Vienna lines]". One Vienna line corresponds to $2.195 \mathrm{~mm}$ (Naegeli \& Schwendener 1892: 294; Johannsen 1914: 623).

Considering that in the original description of $D$. costata (pag. 134), the dimensions are " 1 diam. 1/2 altezza", it is easy to see that the species described by Danilo (1856) exceeds $2 \mathrm{~mm}$ in diameter and therefore cannot be considered as a synonym of $S$. jeffreysii which can slightly exceed one millimeter.

Due to the above reported discrepancy, the aim of this note is to clarify the correct status of the two taxa. 


\section{MATERIAL ANS METHODS}

The examined material includes over one hundred shells of Skeneoides exilissima (Philippi, 1836) from most of the Mediterranean Sea (IN and WR), 6 shells of $S$. jeffreysii from the Sicilian coasts (IN and WR), 11 shells of $S$. jeffreysii (coll. Monterosato, MCZR) and 11 syntypes of Circulus formosissimus Brugnone 1873 (MCZR).

Digital photographs were taken using the Bresser MikroCam II 20 MP 1 camera and the Bresser MikroLab II software for digital processing. Digital photographs at the MCZR were made with Canon Power Shot SX620 HS applied to a binocular microscope.
ABBREVIATIONS. MCZR: Museo Civico di Zoologia, Roma, Italy; IN: Italo Nofroni collection, Roma, Italy; WR: Walter Renda collection, Amantea (Cosenza), Italy

\section{RESULTS}

Monterosato (1872: 31) introduced the name Circulus jeffeysi as follows: "Circulus jeffreysii $s p$. n. Palermo e Trapani come D. costata Dan. e Sand.! Sarà descritto e figurato. [Circulus jeffreysii sp. n. Palermo and Trapani as Delphinula costata Dan. e Sand.! It will be described and figured]". This phrase should not be understood as the creation of

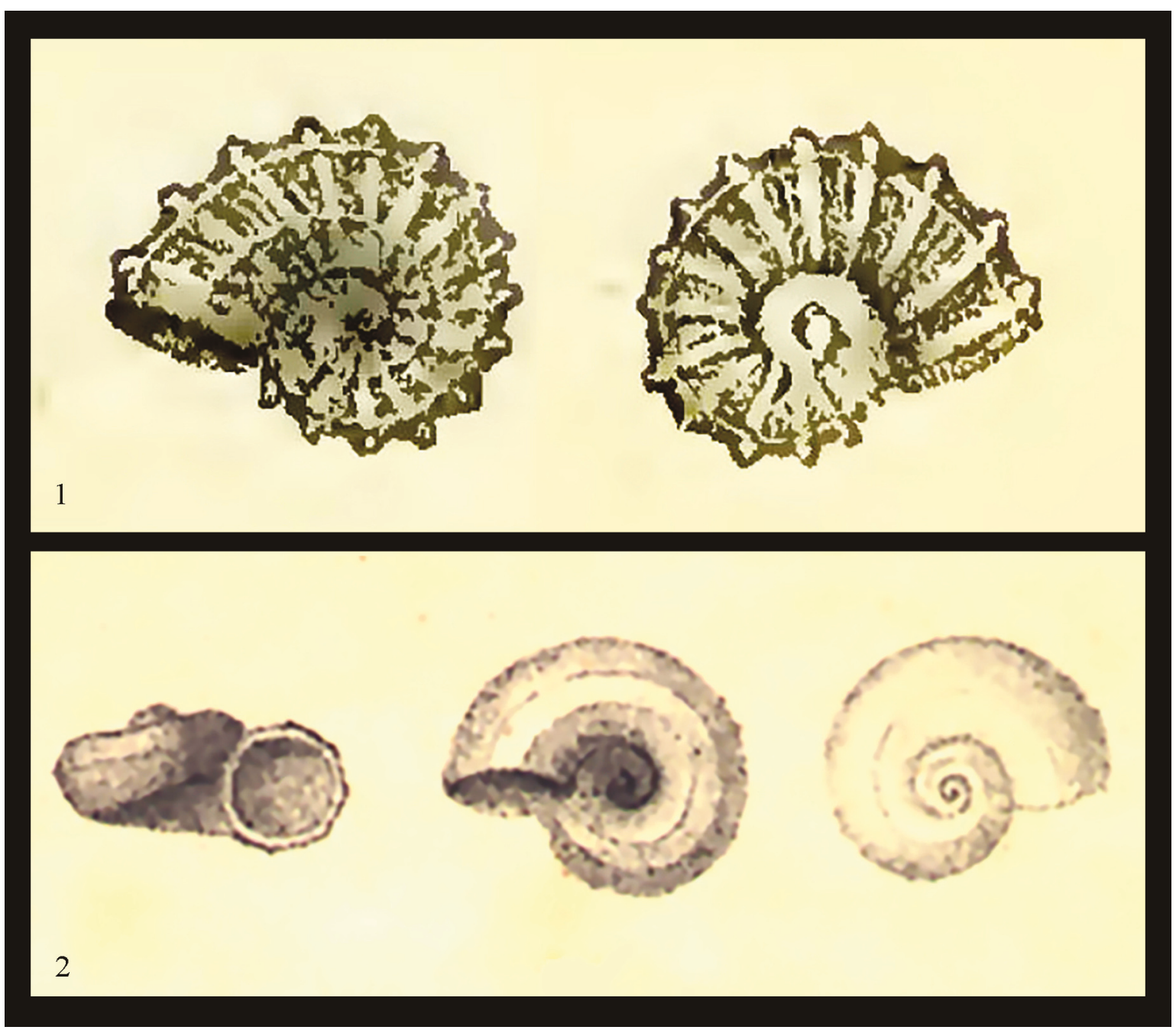

Figure 1. Skeneoides formosissima. Original drawing from Brugnone, 1873, figs 21-22. Figure 2. Skeneoides exilissima. Original drawing from Philippi, 1844, Pl 28, fig. 2. 


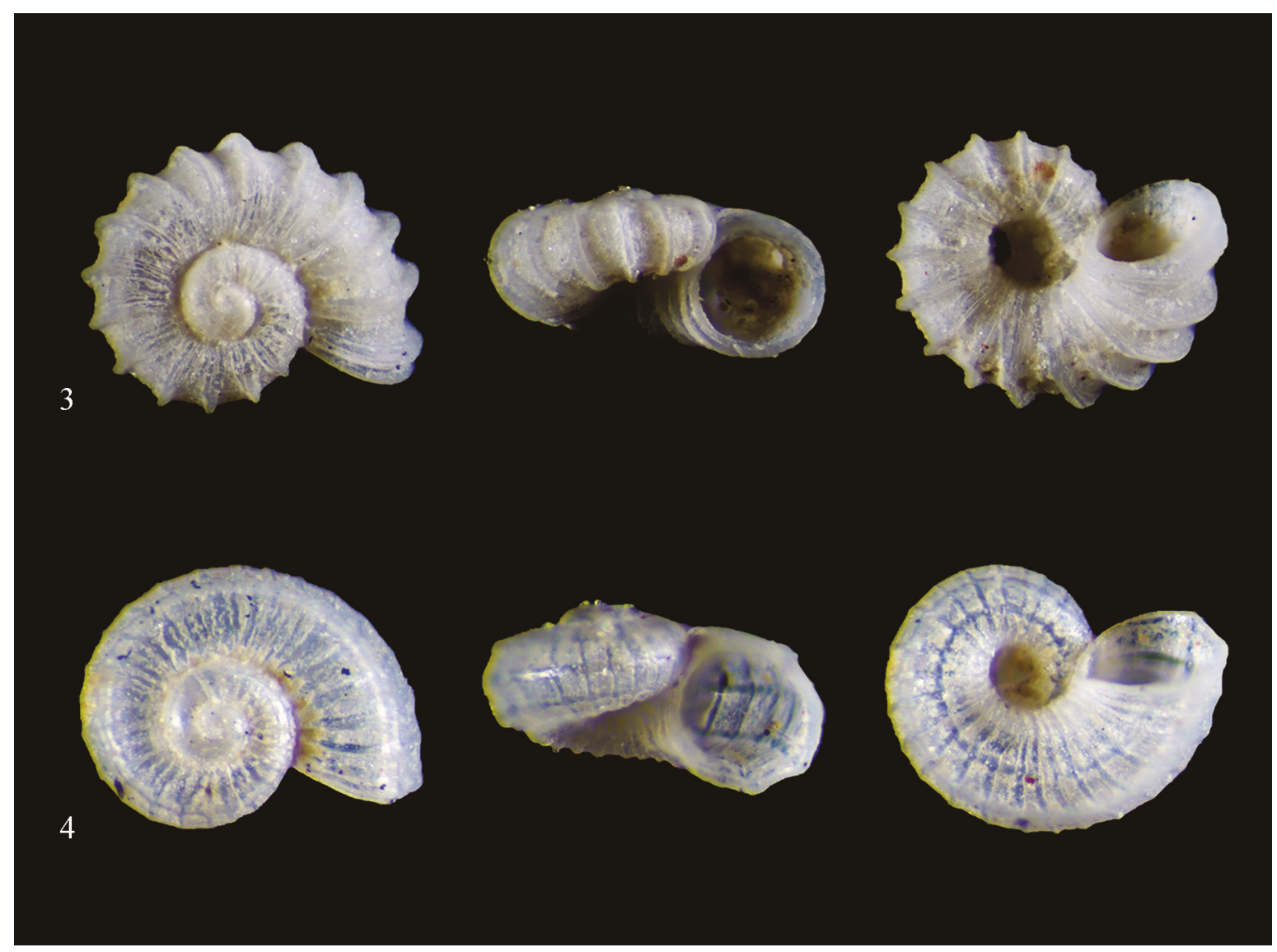

Figure 3. Skeneoides formosissima (mm 1.03), Favignana Island (Trapani, Sicily, Italy) $34 \mathrm{~m}$ (WR).

Figure 4. Skeneoides exilissima (mm 1), Scilla (Reggio Calabria, Calabria, Italy) 35 m (WR).

nomen novum, but simply as a proposal for a name for a species not yet described. Based on this, it is clear that such this name is a nomen nudum, lacking any description or indication (Art. 12 of the Code, ICZN 1999), hence unavailable.

In this respect it is worth reporting what Monterosato states about some of the names introduced in his 1872 work: "Ho fatto un gran conto dei nomi manuscritti, non perché questi abbiano un valore scientifico, ma perché rendendoli di ragion pubblica, possano evitare nuovi inconvenienti e confusioni. [I used a lot of handwritten names, not because they have a scientific value, but because they can avoid new inconveniences and confusions, by being public.]".

The claim by Warén (1992) that it was a replacement name for Delphinula costata is furtherly dispoved by the following passage of Monterosato's 1872 work: “... io fui sorpreso di constatare che la Delphinula costata di Danilo e Sandri non è quella che io conoscevo per tale...è una varietà ad una o più carene della specie che ha ricevuto i nomi di Valvata? striata da Philippi... [... I was surprised to see that Danilo and Sandri's Delphinula costata is not the one I knew as such... is it a variety with one or more kells of the species that has received the names of Valvata? striata by Philippi ... ]" and in fact twenty pages later (: 31) he inserts Delphinula costata in the synonymy of Circulus striatus (Philippi, 1836). Therefore, it was quite clear to Monterosato that Delphinula costata was just another synonym of Circulus striatus and consequently this did not need a replacement name.

As written, Monterosato had promised to describe and illustrate the species, but he was evidently preceded by Brugnone who validly described and figured the new species (1873: 12, figs. 21, 22) with the name Circulus formosissimus 
(currently Skeneoides formosissima (Brugnone, 1873) (Figs. 1, 3, 5-7). Monterosato himself (1874: 260 ) admits that the Brugnone species corresponds to his $C$. jeffreysii.

Appolloni et al. (2018: 25), following Warén (1992), treated this species considering usable the name proposed by Monterosato, thus illustrating a specimen of his collection among the 11 alleged syntypes found (fig. $2 \mathrm{O}, \mathrm{P}$ ) but, in the light of what has been said, this specimen does not constitute typical material.

The type series of $C$. formosissimus is housed in the Monterosato collection (currently in MCZR), since Monterosato bought Brugnone's collection after the death of the latter in 1884 and consists of 11 shells divided into two lots, both with Brugnone's handwritten labels: the first one contains 9 shells (label as in Fig. 5) and the second one 2 syntypes (label as in Fig. 6), we are here illustrating the largest and finest specimen (Fig. 7). The accessione number of the type series is: MCZN-M-21809.

Skenoides formosissima is extremely similar to Skeneoides exilissima (Philippi, 1844), type species of the genus (Figs. 2, 4). Due to the strong variability of the shells of these taxa, small specimens cannot be assigned to one species or to the other and, S. formosissima could be considered

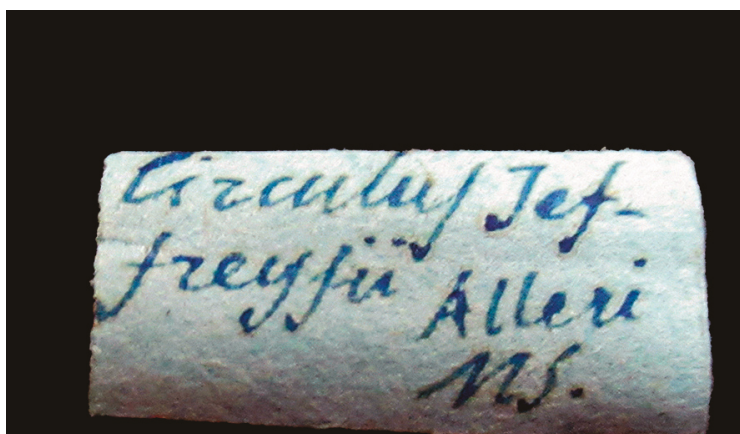

5

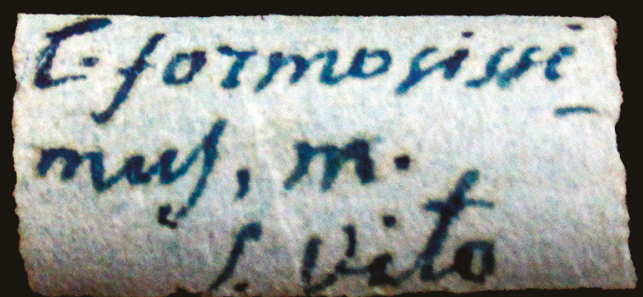

6

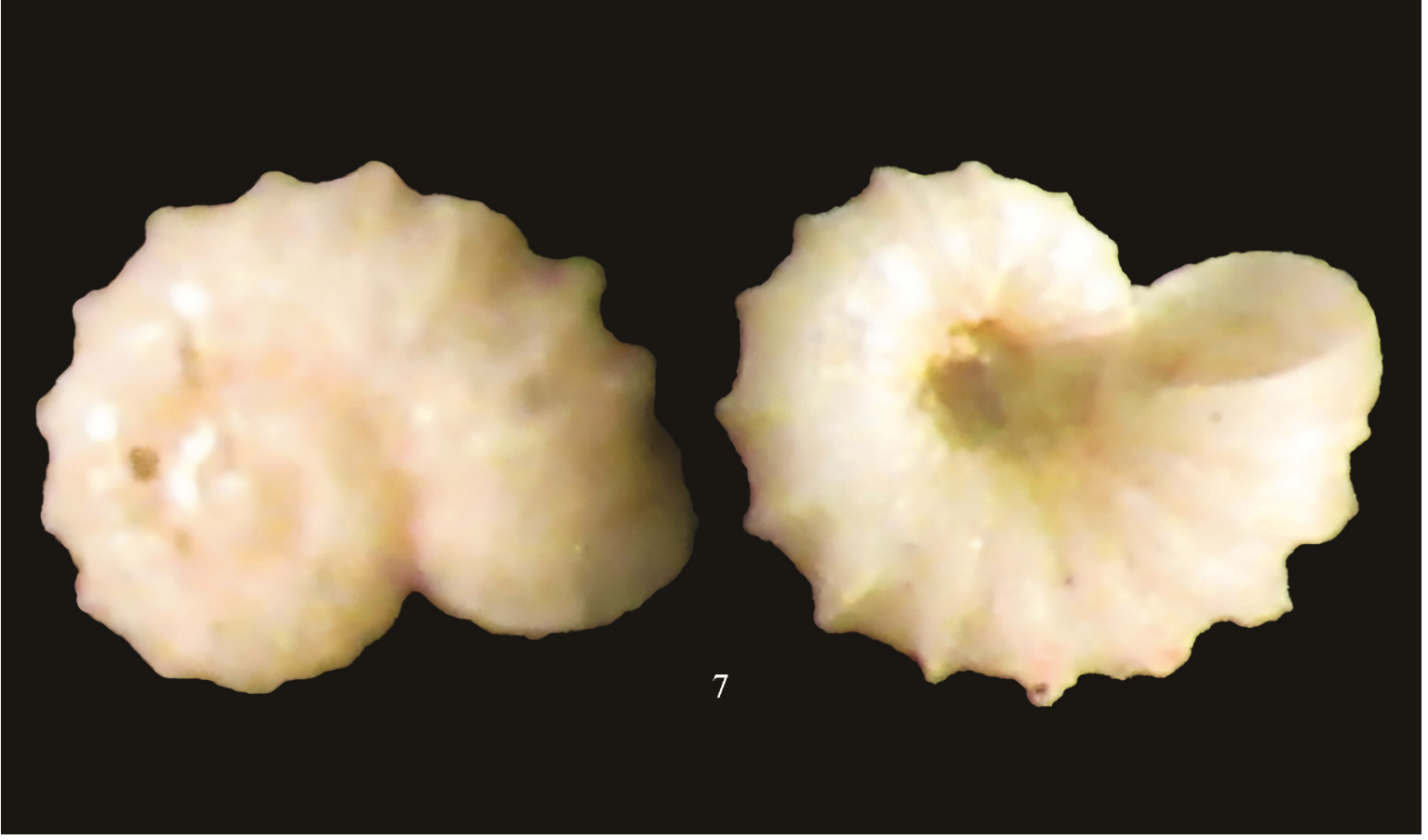

Figures 5-7. Skeneoides formosissima. Fig. 5: Brugnone original label of lot 1. Fig. 6: Brugnone original label of lot 2. Fig. 7: Syntype (mm 1) from lot 2. 
as an extreme form, with massive and arched transverse ribs, of the other, as illustrated in the example by Scaperrotta et al. (2014: 44, front row), where we see a typical $S$. exilissima which, in the last quarter of the teleoconca turn displays the characteristic marked ribs of $S$. formosissima.

Establishing whether the involved taxa represent a single extremely variable species or two distinct species is a problem that goes beyond the aims of this work, hopefully to be soon addressed with a methodology based on the comparison of DNA and not only on the basis of morphological criteria.

\section{CONCLUSIONS}

As a result of the present paper, these are the updated synonymies of the two species treated in this work.

Family SKENEIDAE W. Clark, 1851

Skeneoides exilissima (Philippi, 1844)

= Delphinula exilissima Philippi, 1844 (original combination)

= Cyclostrema dautzenbergianum Ancey, 1898

= Cyclostrema subalveolatum Fekih \& Gougerot, 1974

Skeneoides formosissima (Brugnone, 1873)

= Circulus formosissimus Brugnone, 1873 (original combination)

= Circulus jeffreysii Monterosato, 1872 (nomen nudum, unavailable)

\section{ACKNOWLDGMENTS}

A sincere thanks to our friends Bruno Amati (Roma, Italy) for the useful suggestions and Massimo Appolloni (Roma, MCZR, Italy) for providing us with the typical material of Circulus formosissimus.

\section{REFERENCES}

Appolloni M., Smriglio C., Amati B., Lugliè L., Nofroni I., Tringali LP, Mariottini P. \& Oliverio M.,
2018. Catalogue of the primary types of marine molluscan taxa described by Tommaso Allery Di Maria, Marquis of Monterosato, deposited in the Museo Civico di Zoologia, Roma. Zootaxa, 4477 (1): $1-138$.

Brown T., 1827. Illustrations of the conchology of Great Britain and Ireland. Drawn from nature. W.H. Lizars and D. Lizars. Edinburgh and S. Highley, 144 pp.

Brugnone G., 1873. Miscellanea malachologica. Pars prima. Ex typographia Michaelis Amenta, Palermo, $15 \mathrm{pp}$.

Danilo F., 1856. Elenco nominale dei gasteropodi testacei marini raccolti nei dintorni di Zara, e determinati dal Sig. Giovanni Battista Sandri e dal Prof. Dr. Francesco Danilo. Programma dell'I. R. Ginnasio completo di prima classe in Zara alla fine dell'anno scolastico 1855-56. Tipografia Governiale, Zara: 107-150.

[Bibliographic note. This work has usually been attributed to Danilo \& Sandri or to Sandri \& Danilo. In reality, the two names on the front page are part of the title and the only author, as in the previous contribution (1855) on bivalves, is Danilo whose name does not appear explicitly, but is reported in the final index. The only one, to our knowledge, who quoted it correctly is Warén (1992)].

ICZN, 1999. International Code on Zoological Nomenclature, 4th Edition, adopted by the International Union of Biological Sciences. Ed. Australian National University, Camberra, Australia.

Johannsen A., 1914. Manual of Petrographic Methods. McGraw-Hill Book Company, New York, 704 pp.

Monterosato T.A., 1872. Notizie intorno alle conchiglie Mediterranee. Ufficio tipografico di Michele Amenta, Palermo, $61 \mathrm{pp}$.

Monterosato T.A., 1874. Recherches Conchyliologiques effectuées au cap Santo Vito, en Sicile. Journal de Conchyliologie, 22: 243-282.

Naegeli KW. \& Schwendener S., 1892. The microscope in theory and practice. MacMillan \& Co. London, 382 pp.

Philippi R.A., 1844. Enumeratio molluscorum Siciliae cum viventium tum in tellure tertiaria fossilium, quae in itinere suo observavit. Vol. 2. Halle [Halis Saxorum]: Eduard Anton. iv + 303 pp., pls 13-28.

Romani L., Raveggi A., Scaperrotta M. \& Bartolini S., 2018. Contributo alla conoscenza della malacofauna marina delle isole adriatiche. 1 . Nota sui micromolluschi marini conchiferi rinvenuti sulla costa settentrionale dell'isola di Lastovo [Lagosta](Croazia, Mar Adriatico Sud-Orientale). Alleryana, 36: 1-22.

Scaperrotta M., Bartolini S. \& Bogi C., 2014, Accrescimenti: stati di accrescimento dei Molluschi marini mediterranei, Vol. 6. L'Informatore Piceno Ed. Ancona, 192 pp. 
Warén A., 1992. New and little known "skeneimorph" gastropods from the Mediterranean Sea and the adja- cent Atlantic Ocean. Bollettino Malacologico, 27: 149-248. 